\title{
Lannea microcarpa: A Review of its Medicinal Uses, Phytochemistry and Pharmacological Properties
}

\author{
Alfred Maroyi \\ Medicinal Plants and Economic Development Research Centre, Department of Botany, University of Fort \\ Hare, Alice, South Africa
}

\begin{abstract}
Lannea microcarpa is an important food plant and herbal medicine in West Africa. The present study critically reviewed the medicinal uses, phytochemistry and pharmacological properties of $L$. microcarpa. The keywords including L. microcarpa, its synonyms, English common names, medicinal uses, phytochemistry and pharmacological properties were searched using electronic databases such as ISI web of knowledge, ProQuest, science direct, OATD, scopus, Open-thesis, pubmed and google scholar. The search for pre-electronic literature such as conference papers, scientific articles, books, book chapters, dissertations and theses were carried out at the University library. Literature studies revealed that $L$. microcarpa is used as herbal medicine in $58.3 \%$ of the countries where the species is indigenous. The major diseases treated by L. microcarpa extracts include fever and malaria, gastro-intestinal problems, ulcers and wounds, respiratory problems, pain and musculoskeletal disorder, haemorrhoids, intestinal worms and skin diseases and used as ethnoveterinary medicine. Phytochemical compounds identified from the species include amino acids, anthocyanins, fatty acids, flavonoids, myricetin glycosides, phenolic compounds and triglycerides. Pharmacological studies revealed that $L$. microcarpa extracts have antibacterial, antifungal, antihypertensive, anti-inflammatory, antioxidant, antiprotozoal and antitrypanosomal, inhibition of a-amylase, shea butter stabilization and trypsin inhibition activities. Detailed studies are required aimed at establishing the efficacy, clinical relevance, safety and mechanisms of action of the plant extracts and its compounds.
\end{abstract}

Keywords: Anacardiaceae, ethnopharmacology, herbal medicine, Lannea microcarpa, West Africa.

\section{INTRODUCTION}

Lannea microcarpa Engl. \& K. Krause is a member of the cashew or Anacardiaceae family. The name of the genus, "Lannea" is based on a Latin word "lana" which translates to "wool" in reference to young plant parts which are densely hairy or possibly to the wool on the roots of some Lannea species [1]. Lannea microcarpa is a deciduous tree with dense, semispherical crown, which grows up to $16 \mathrm{~m}$ in height [2]. The tree is indigenous to Benin, Cameroon, Côte d'Ivore, Gambia, Ghana, Guinea, Mali, Niger, Nigeria, Senegal and Togo. It has been recorded in the savannah biome, common in deep friable soil and rocky soil especially in the Sahel savanna [2]. Lannea microcarpa is regarded as a multipurpose tree in West Africa, harvested from the wild to provide food, medicines, fibre, dye, handicrafts, woodcarving and fuel for the local people [2]. Young leaves of $L$. microcarpa leaves are eaten as leafy vegetables [2] and seeds are important sources of edible oil and the oil can be used in animal feeds and cosmetics [3] and biodiesel production [4]. Due to its high use value, $L$. microcarpa is often protected by farmers during land clearing in Benin and Burkina Faso $[5,6]$ and the

*Address correspondence to this author at the Medicinal Plants and Economic Development Research Centre, Department of Botany, University of Fort Hare, Alice, South Africa; Tel: +27719600326; E-mail: amaroyi@ufh.ac.za

ISSN: 2223-3806 / E-ISSN: 1927-5951/18 species is tolerated in agroforestry parklands and also protected in home gardens in northern Bénin [5]. Research by Diop [5] revealed that $L$. microcarpa is the third important indigenous fruit tree in Mali and the species is also ranked as the sixth most valued indigenous fruit tree in Benin [8]. Therefore, the fruits of L. microcarpa are traded commercially in Benin [9], Burkina Faso [10] and Nigeria [11] and the different plant parts are sold in informal herbal medicine markets as herbal medicines in Benin [9]. As L. microcarpa is mostly collected from the wild, the species population is declining and vulnerable in Burkina Faso $[12,13]$, threatened with extinction in Benin [14] and threatened also in Nigeria mainly because of urbanization, deforestation, expansion of agricultural activities and unsustainable collection [15]. It is within this context that this review was undertaken aimed at summarizing the medicinal uses, phytochemical and pharmacological properties of $L$. microcarpa so as to provide baseline data required for evaluating the therapeutic potential of the species.

\section{Medicinal Uses of L. microcarpa}

The aerial parts, bark, fruits, gums, leaves, roots, seeds, stem bark and wood ash of L. microcarpa are used as herbal medicines against 46 and three human and animal diseases, respectively (Table 1). The medicinal uses of $L$. microcarpa are recorded in Benin, Burkina Faso, Cameroon, Ghana, Mali, Nigeria and 
Table 1: Medicinal Uses of L. microcarpa

\begin{tabular}{|c|c|c|c|}
\hline Medicinal use & Parts of the plant used & Country & References \\
\hline Abortifacient & Stem bark & Nigeria & [18] \\
\hline After birth & Bark, fruits, leaves and roots & Benin & [13] \\
\hline Anaemia & Bark, fruits, leaves and roots & Benin & {$[13,19]$} \\
\hline Blisters & Bark, fruits, leaves and roots & Nigeria & [2] \\
\hline Boils, carbuncles and furuncles & Bark, fruits, leaves and roots & Nigeria & {$[2,20]$} \\
\hline Cathartic & Bark, fruits, leaves and roots & Nigeria & [2] \\
\hline Colic & Aerial parts & Benin & [2] \\
\hline Elephantiasis & Stem bark & Cameroon & [26] \\
\hline Eye problems & Bark, fruits, leaves and roots & Benin & [13] \\
\hline $\begin{array}{l}\text { Fever and malaria (including } \\
\text { brucellosis, paludism and } \\
\text { trypanosomosis) }\end{array}$ & Bark, fruits, leaves, roots and stem bark & $\begin{array}{l}\text { Benin, Burkina } \\
\text { Faso, Mali and } \\
\text { Nigeria }\end{array}$ & {$[13,23,25,27-29]$} \\
\hline Haemorrhoids & Bark, fruits, leaves, roots and stem bark & $\begin{array}{l}\text { Benin and Burkina } \\
\text { Faso }\end{array}$ & {$[13,23]$} \\
\hline Hematuria & Stem bark & Burkina Faso & [24] \\
\hline Pain and musculoskeletal disorders & Aerial parts, bark, fruits, leaves, roots and stem bark & $\begin{array}{l}\text { Benin, Burkina } \\
\text { Faso and Nigeria }\end{array}$ & {$[2,23]$} \\
\hline Premature birth & Bark & Benin & [31] \\
\hline $\begin{array}{l}\text { Prevention of oral diseases and } \\
\text { toothache }\end{array}$ & Leaves & Burkina Faso & [32] \\
\hline Rickets & Fruits & Burkina Faso & [21] \\
\hline Scurvy & Fruits & Burkina Faso & [21] \\
\hline Skin diseases and varicella & Bark, fruits, leaves and roots & Benin and Ghana & {$[13,22]$} \\
\hline Snake bite & Bark, fruits, leaves and roots & Benin & [13] \\
\hline Suppress appetite & Fruits & Burkina Faso & {$[33]$} \\
\hline Ulcers and wounds & Bark, fruits, leaves and roots & $\begin{array}{l}\text { Benin, Ghana, Mali } \\
\text { and Nigeria }\end{array}$ & {$[2,11,13,34]$} \\
\hline Wounds & $\begin{array}{l}\text { Leaves and fruits are mixed with dried stem and leaves } \\
\text { of Cissus quadrangularis } \mathrm{L} \text {. }\end{array}$ & Mali & [16] \\
\hline $\begin{array}{l}\text { Ethnoveterinary medicine (brucellosis } \\
\text { and trypanosomosis) }\end{array}$ & Leaves and stem bark & $\begin{array}{l}\text { Benin, Burkina } \\
\text { Faso and Mali }\end{array}$ & {$[27,28,35,36]$} \\
\hline Anthelmintic & $\begin{array}{l}\text { Leaves mixed with Boscia senegalensis (Pers.) Lam. } \\
\text { ex Poir. and Parkia biglobosa (Jacq.) R. Br. ex G. Don }\end{array}$ & Burkina Faso & [17] \\
\hline
\end{tabular}




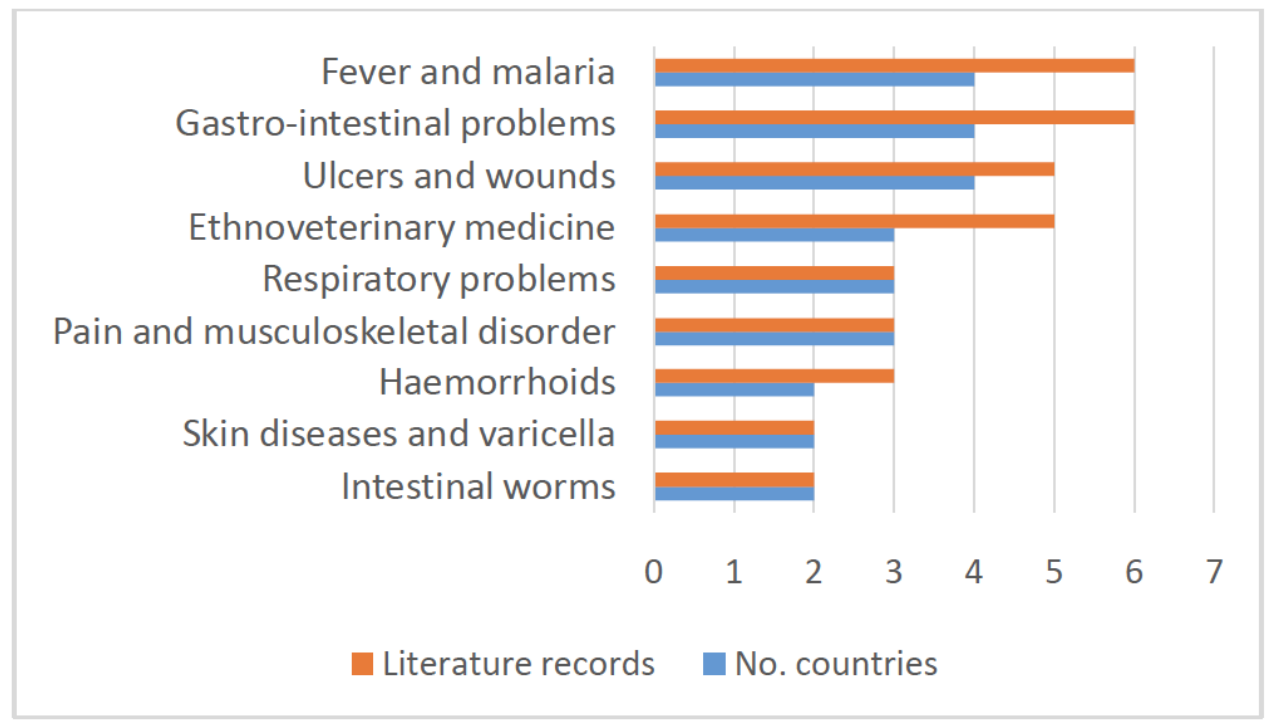

Figure 1: Main medicinal uses of L. microcarpa.

Senegal, representing $58.3 \%$ of the countries where the species is indigenous (Table 1). Lannea microcarpa is used as herbal medicine against the following major diseases and ailments (in descending order of importance): fever and malaria, gastro-intestinal problems, ulcers and wounds, ethnoveterinary medicine, respiratory problems, pain and musculoskeletal disorder, haemorrhoids, intestinal worms, skin diseases and varicella (Figure 1). In multitherapeutic applications, the leaves and fruits of $L$. microcarpa are applied topically on wounds mixed with dried stems and leaves of Cissus quadrangularis L. [16] while the leaves of $L$. microcarpa are mixed with those of Boscia senegalensis (Pers.) Lam. ex Poir. and Parkia biglobosa (Jacq.) R. Br. ex G. Don and used as an anthelmintic [17].

\section{Phytochemistry and Pharmacological Properties of L. microcarpa}

A variety of phytochemicals and mineral elements have been identified from the the bark, fruit pulp, leaves and seed oil of L. microcarpa (Table 2). Flavonoids and phenolic compounds which enhance the antioxidant capacities of the species have been identified [21,37-39]. Glew et al. [40] and Bationo et al. [21] identified amino acids, fatty acids, mineral elements and other nutritional components including calcium, carbohydrates, iron, magnesium, manganese, phosphorus and proteins from the fruit pulp and seed oil of the species (Table 2). Seeds of $L$. microcarpa are characterized by high crude oil and protein content that make them valuable as animal feed or for human nutrition and cosmetics [3,21]. Pale et al. [41] identified anthocyanins, cyanidin 3-0-(2-0- $\beta-D x y l o p y r a n o s y l) ~ \beta-D-$ galactopyranoside and cyanidin 3-0- $\beta$-D- galactopyranoside from fruits of $L$. microcarpa while Picerno et al. [42] identified 4'-methoxymyricetin 3-O-aL-rhamnopyranoside, myricetin 3-O- $\alpha-\mathrm{L}-$ rhamnopyranoside, myricetin 3-O- $\beta$-Dglucopyranoside, vitexin, isovitexin, gallic acid and epicatechin from leaf extracts of the species.

The pharmacological activities exhibited by $L$. microcarpa extracts include the following: antibacterial $[21,38,45]$, antifungal [45], antihypertensive $[46,47]$, anti-inflammatory $[42,48,49]$, antioxidant $[21,37$ $39,48,50]$, antiprotozoal and antitrypanosomal [35,51], inhibition of a-amylase [39], shea butter stabilization [39] and trypsin inhibition [39] activities.

\section{Antibacterial Activities}

Ouattara et al. [38] evaluated antibacterial activities of ethaonol bark extracts of L. microcarpa against Bacillus subtilus, Enterobacter aerogenes, Enterococcus faecalis, Proteus mirabilis, Pseudomonas aeruginosa, Salmonella enterica, Salmonella typhimurium, Staphylococcus aureus and Staphylococcus camorum using disc diffusion and broth micro dilution methods with ciprofloxacin, erythromycin and tetracyclin as positive controls. The extracts exhibited activities against tested pathogens with $9 \mathrm{~mm}$ to $17 \mathrm{~mm}$ zone of inhibition, minimum inhibitory concentration (MIC) values ranging from 7.8 $\mu \mathrm{g} / \mathrm{mL}$ to $125.0 \mu \mathrm{g} / \mathrm{mL}$ and minimum bactericidal concentration (MBC) values ranging from $31.3 \mu \mathrm{g} / \mathrm{mL}$ to $250.0 \mu \mathrm{g} / \mathrm{mL}$ [38]. Bationo et al. [21] evaluated antibacterial activities of butanol and ethyl acetate fruit and leaf extracts of $\mathrm{L}$. microcarpa against Bacillus cereus, Escherichia coli, Proteus mirabilis, Salmonella typhimurium, Shigella dysenteria and Staphylococcus 
Table 2: Nutritional and Phytochemical Composition of the Bark, Fruit Pulp, Leaves and Seed Oil of L. microcarpa

\begin{tabular}{|c|c|c|c|}
\hline Nutritional and phytochemical composition & Value & Plant part & References \\
\hline Ash (\%) & $3.1 \pm 0.2$ & Seed oil & [3] \\
\hline Calcium $(\mu \mathrm{g} / \mathrm{g})$ & 6440 & Fruit & [40] \\
\hline Carbohydrates (\%) & $10.9 \pm 1.6$ & Seed oil & [3] \\
\hline Iron $(\mu \mathrm{g} / \mathrm{g})$ & 16.6 & Fruit & [40] \\
\hline Lipids (\%) & $64.9 \pm 1.3$ & Seed oil & [3] \\
\hline Magnesium $(\mu \mathrm{g} / \mathrm{g})$ & 2420 & Fruit & [40] \\
\hline Manganese $(\mu \mathrm{g} / \mathrm{g})$ & 14.3 & Fruit & [40] \\
\hline Moisture (\%) & $3.2-28$ & Seed oil & {$[3,44,45]$} \\
\hline Phosphorus $(\mu \mathrm{g} / \mathrm{g})$ & 1670 & Fruit & [40] \\
\hline Proteins (\%) & $21.1 \pm 0.3$ & Seed oil & [3] \\
\hline \multicolumn{4}{|l|}{ Amino acids } \\
\hline Alanine $(\mathrm{mg} / \mathrm{g})$ & 2.3 & Fruit & [40] \\
\hline Arginine $(\mathrm{mg} / \mathrm{g})$ & 2.9 & Fruit & [40] \\
\hline Aspartic acid (mg/g) & 3.7 & Fruit & [40] \\
\hline Cysteine $(\mathrm{mg} / \mathrm{g})$ & 0.9 & Fruit & [40] \\
\hline Glutamic acid $(\mathrm{mg} / \mathrm{g})$ & 4.4 & Fruit & [40] \\
\hline Glycine (mg/g) & 1.6 & Fruit & [40] \\
\hline Histidine $(\mathrm{mg} / \mathrm{g})$ & 1.0 & Fruit & [40] \\
\hline Isoleucine (mg/g) & 1.7 & Fruit & [40] \\
\hline Leucine $(\mathrm{mg} / \mathrm{g})$ & 2.6 & Fruit & [40] \\
\hline Lysine $(\mathrm{mg} / \mathrm{g})$ & 1.6 & Fruit & [40] \\
\hline Methionine $(\mathrm{mg} / \mathrm{g})$ & 0.4 & Fruit & [40] \\
\hline Phenylalanine $(\mathrm{mg} / \mathrm{g})$ & 1.6 & Fruit & [40] \\
\hline Proline $(\mathrm{mg} / \mathrm{g})$ & 9.5 & Fruit & [40] \\
\hline Serine $(\mathrm{mg} / \mathrm{g})$ & 1.7 & Fruit & [40] \\
\hline Threonine (mg/g) & 1.6 & Fruit & {$[40]$} \\
\hline Tryptophan (mg/g) & 3.7 & Fruit & [40] \\
\hline Tyrosine $(\mathrm{mg} / \mathrm{g})$ & 1.1 & Fruit & [40] \\
\hline Valine (mg/g) & 2.1 & Fruit & {$[40]$} \\
\hline \multicolumn{4}{|l|}{ Fatty acid } \\
\hline Behenic acid (mg/g) & $0.2 \pm 0.01$ & Seed oil & [3] \\
\hline Eicosanoic acid (mg/g) & $0.9 \pm 0.03$ & Seed oil & [3] \\
\hline Eicosenoic acid (mg/g) & $0.3 \pm 0.01$ & Seed oil & [3] \\
\hline Heptadecanoic acid (mg/g) & $0.2 \pm 0.0$ & Seed oil & [3] \\
\hline Linoleic acid $(\mathrm{mg} / \mathrm{g})$ & $11.2 \pm 0.1$ & Seed oil & [3] \\
\hline Linolenic acid $(\mathrm{mg} / \mathrm{g})$ & $0.4 \pm 0.1$ & Seed oil & [3] \\
\hline Linoleic acid $(\mathrm{mg} / \mathrm{g})$ & 0.1 & Fruit & [40] \\
\hline Linolenic acid (mg/g) & 0.03 & Fruit & [40] \\
\hline Oleic acid $(\mathrm{mg} / \mathrm{g})$ & 0.1 & Fruit & [40] \\
\hline Oleic acid $(\mathrm{mg} / \mathrm{g})$ & $43.5 \pm 0.2$ & Seed oil & [3] \\
\hline Trans Oleic acid $(\mathrm{mg} / \mathrm{g})$ & $0.6 \pm 0.1$ & Seed oil & [3] \\
\hline
\end{tabular}


(Table 2). Continued.

\begin{tabular}{|c|c|c|c|}
\hline Nutritional and phytochemical composition & Value & Plant part & References \\
\hline Palmitoleic acid (mg/g) & 0.02 & Fruit & {$[40]$} \\
\hline Palmitic acid (mg/g) & 0.2 & Fruit & {$[40]$} \\
\hline Palmitic acid (mg/g) & $34.5 \pm 0.4$ & Seed oil & [3] \\
\hline Stearic acid (mg/g) & $8.4 \pm 0.2$ & Seed oil & [3] \\
\hline Stearic acid (mg/g) & 0.04 & Fruit & {$[40]$} \\
\hline \multicolumn{4}{|l|}{ Triglyceride } \\
\hline Dilinoleyol olein (\%) & $2.5 \pm 0.03$ & Seed oil & [3] \\
\hline Dipalmitoyl linolein (\%) & $10.9 \pm 0.07$ & Seed oil & [3] \\
\hline Dipalmitoyl olein (\%) & $16.5 \pm 0.1$ & Seed oil & [3] \\
\hline Distearoyl olein (\%) & $1.5 \pm 0.02$ & Seed oil & [3] \\
\hline Linoleyol diolein (\%) & $9.3 \pm 0.0$ & Seed oil & [3] \\
\hline Palmitoyl dilinolein (\%) & $5.1 \pm 0.3$ & Seed oil & [3] \\
\hline Palmitoyl diolein (\%) & $21.2 \pm 0.5$ & Seed oil & [3] \\
\hline Palmitoyl linolenoyl olein (\%) & $1.5 \pm 0.02$ & Seed oil & [3] \\
\hline Palmitoyl linoleyl olein (\%) & $12.0 \pm 0.3$ & Seed oil & [3] \\
\hline Palmitoyl oleoyl stearin (\%) & $6.5 \pm 0.01$ & Seed oil & [3] \\
\hline Stearoyl diolein (\%) & $3.7 \pm 0.1$ & Seed oil & [3] \\
\hline Stearoyl linoleyl olein (\%) & $3.0 \pm 0.03$ & Seed oil & [3] \\
\hline Triolein (\%) & $6.2 \pm 0.3$ & Seed oil & [3] \\
\hline Total polyphenol (mg GAE /g dry weight) & $1.4 \pm 0.05$ & Seed oil & [3] \\
\hline a-tecopherol (ppm) & $89.4 \pm 0.6$ & Seed oil & [3] \\
\hline Y-tecopherol (ppm) & $437.2 \pm 1.7$ & Seed oil & [3] \\
\hline$\delta$-tecopherol (ppm) & $51.9 \pm 0.1$ & Seed oil & [3] \\
\hline Total flavonoid content (g quercetin equivalents/100 g of extract) & $0.3-35.4$ & Bark, leaves and fruits & {$[21,37,38]$} \\
\hline $\begin{array}{c}\text { Total phenolic content (g gallic acid equivalents } / 100 \mathrm{~g} \text { of lyophilized } \\
\text { extract) }\end{array}$ & $1.2-1006.8$ & $\begin{array}{l}\text { Bark, fruits, leaves and } \\
\text { seed oil }\end{array}$ & {$[21,37,38,39]$} \\
\hline \multicolumn{4}{|l|}{ Myricetin glycosides } \\
\hline 4'-methoxy-myricetin 3-O-a-L-rhamnopyranoside & & Leaves & {$[42]$} \\
\hline Myricetin 3-O- $\beta$-D-glucopyranoside & & Leaves & {$[42]$} \\
\hline Myricetin 3-O- $\alpha-L-$ rhamnopyranoside & & Leaves & {$[42]$} \\
\hline \multicolumn{4}{|l|}{ Flavonoid } \\
\hline Epi-catechin & & Leaves & {$[42]$} \\
\hline \multicolumn{4}{|l|}{ Trihydroxybenzoic acid } \\
\hline Gallic acid & & Leaves & {$[42]$} \\
\hline \multicolumn{4}{|l|}{ Flavone } \\
\hline Isovitexin & & Leaves & {$[42]$} \\
\hline Vitexin & & Leaves & {$[42]$} \\
\hline \multicolumn{4}{|l|}{ Anthocyanin } \\
\hline Cyanidin 3-0-(2-0- $\beta$-Dxylopyranosyl) $\beta$-D-galactopyranoside & & Fruits & {$[41]$} \\
\hline Cyanidin 3-0- $\beta-D-g a l a c t o p y r a n o s i d e$ & & Fruits & {$[41]$} \\
\hline
\end{tabular}


aureus using disc diffusion and broth micro dilution methods with DMSO as negative control, ampicillin and ciprofloxacin as positive controls. The extracts exhibited activities with inhibition diameter ranging from $7.0 \mathrm{~mm}$ to $17.5 \mathrm{~mm}$. The MIC values ranged from 0.2 $\mathrm{mg} / \mathrm{mL}$ to $10.0 \mathrm{mg} / \mathrm{mL}$ [21]. Similarly, Danladi et al. [45] evaluated antibacterial activities of aqueous bark and leaf extracts of L. microcarpa against Pseudomonas syringae using agar well diffusion method. Only leaf extracts were active at $20 \mathrm{mg} / \mathrm{ml}, 40 \mathrm{mg} / \mathrm{ml}$ and 80 $\mathrm{mg} / \mathrm{ml}$ which exhibited inhibition of $5.5 \%, 16.7 \%$ and $16.7 \%$, respectively [45]. These antibacterial activities exhibited by extracts of L. microcarpa support the traditional usage of the species as remedy for bacterial infections such as abscesses [2], blisters [2], boils [2], carbuncles [20], diarrhoea [9], dysentery [2,9], furuncles [15], prevention of oral diseases [32], skin diseases [22], stomach ache $[9,22,23]$, toothache [32] and wounds $[2,9,11,16,32,34]$.

\section{Antifungal Activities}

Danladi et al. [45] evaluated antifungal activities of aqueous bark and leaf extracts of $L$. microcarpa against Aspergillus niger and Fusarium oxysporium using agar impregnation method. Both bark and leaf extracts were active against Fusarium oxysporium at $20 \mathrm{mg} / \mathrm{ml}, 40 \mathrm{mg} / \mathrm{ml}$ and $80 \mathrm{mg} / \mathrm{ml}$ which exhibited inhibition rate ranging from $11.1 \%$ to $33.3 \%$. Only leaf extracts were active against Aspergillus niger at 40 $\mathrm{mg} / \mathrm{ml}$ and $80 \mathrm{mg} / \mathrm{ml}$ which exhibited inhibition of $4.4 \%$ and $22.2 \%$, respectively [45]. These findings support the traditional use of $L$. microcarpa against fungal and microbial infections such as wounds $[2,9,11,16,32,34]$.

\section{Antihypertensive Activities}

Ouedraogo et al. [46] evaluated the vasorelaxant and phosphodiesterases inhibition activities of aqueous, dichloromethane and ethyl acetate leaf extracts of $L$. microcarpa. The acculative addition of aqueous extracts caused concentration-dependent relaxation response in both aortas with endotheliumintact and endothelium-denuded aortas and ethyl acetate inhibited phenylephrine-induced vasoconstriction. The extracts were able to inhibit phosphodiesterases and Ouedraogo et al. [46] argued that the vascular smooth muscle relaxation properties were due to phosphodiesterases inhibition activities. Similarly, Nitiema et al. [47] evaluated hypotensive and preventive activities of aqueous, methylene and ethyl acetate leaf extracts of $L$. microcarpa on anesthetized normotensive blood pressure of Wistar Rat. High blood pressure was induced by adrenaline $(75 \mu \mathrm{g} / \mathrm{kg})$ and phenylephrine $(100 \mu \mathrm{g} / \mathrm{kg})$ administration after administering the extracts. The extracts induced a transient hypotensive effect on normotensive anesthetized rat in dose-dependent manner. On adrenaline and phenylephrine-induced high blood pressure, all extracts caused a dose dependent inhibitory effect by single preventive doses of 0.03 $\mathrm{mg} / \mathrm{kg}$ to $10 \mathrm{mg} / \mathrm{kg}$ when administered 5 minutes before the agonists. The best effects of the extracts tested have been obtained with the crude extract and the ethyl acetate fraction of L. microcarpa [47]. These findings corroborate the traditional usage of $L$. microcarpa bark as herbal medicine for hypertension in Burkina Faso [30].

\section{Anti-Inflammatory Activities}

Picerno et al. [42] evaluated anti-inflammatory activities of leaf extracts of $L$. microcarpa using the inhibition of the croton-oil-induced ear oedema in mice with the non-steroidal anti-inflammatory drug indometacin as control. The extract showed antiinflammatory activities with infectious dose $\left(I_{50}\right)$ value of $900 \mu \mathrm{gcm}^{-2}$ which was ten times lower than the $\mathrm{ID}_{50}$ value of $93 \mu \mathrm{gcm}^{-2}$ demonstrated by indomethacin, the non-steroidal anti-inflammatory drug used as reference [42]. Bationo et al. [48] evaluated anti-inflammatory activities of crude hydro-acetonic fruit and leaf extracts of $L$. microcarpa using the carrageenan induced paw edema in mice, the inhibitory effects of the extracts on the lipoxygenase, xanthine oxidase and lipid peroxidation. At the doses of $100 \mathrm{mg} / \mathrm{kg}, 200 \mathrm{mg} / \mathrm{kg}$, $400 \mathrm{mg} / \mathrm{kg}$, the extracts of both the fruit and leaf reduced the carrageenan-induced paw edema while the dose of $200 \mathrm{mg} / \mathrm{kg}$ produced a maximum percentage of inhibition of mice paw edema both for fruit $(78.4 \%)$ and leaf $(58.0 \%)$ at the fifth hour compared to control. Significant lipoxigenase and xanthine oxidase inhibitory effect was obtained with both fruit and leaf extract. The fruit and leaf extracts inhibited lipid peroxidation with $32.9 \%$ and $78.1 \%$, respectively [48]. Similarly, Antwi-Adjei et al. [49] evaluated anti-inflammatory activities of aqueous stem bark extract of $L$. microcarpa using the extran sulphateinduced paw oedema in Sprague Dawley rats. The extracts reduced the mean maximal paw oedema in a dose dependent manner when compared to the control. Similarly, the extracts reduced percentage mean oedema in xylene-induced ear oedema in a dose dependent manner when compared to the control [49]. These findings support the use of $L$. microcarpa extracts as herbal medicine against abscesses [2], 
blisters [2], boils [2], carbuncles [20], furuncles [20], musculoskeletal disorders [23], pain [2], rheumatism [2] and wounds $[2,9,11,16,32,34]$.

\section{Antioxidant Activities}

Lamien-Meda et al. [37] evaluated antioxidant activities of acetone and methanol fruit extracts of $L$. microcarpa using the 2,2-dipheny-l-picrylhydrazyl (DPPH), ferric reducing antioxidant capacity (FRAP) and 2,2'-azinobis-3-ethylbenzothiazoline-6-sulphonate (ABTS) assays. The DPPH radical scavenging results ranged from 400 to $3800 \mathrm{mg} A E A C / 100 \mathrm{~g}$, FRAP (2.5 to $12.5 \mathrm{mmol} A E A C / 100 \mathrm{~g}$ ) and ABTS (136 to $230 \mu \mathrm{mol}$ $A E A C / 100$ g) [37]. Ouattara et al. [38] evaluated antioxidant activities of ethanol bark extracts of $L$. microcarpa using the DPPH free radical scavenging assay with gallic acid and quercetin as positive controls. The extract exhibited half maximal inhibitory concentration $\left(\mathrm{IC}_{50}\right)$ value of $450.3 \mu \mathrm{g} / \mathrm{mL}$, while the controls, gallic acid and quercetin exhibited much lower $\mathrm{IC}_{50}$ values of $0.6 \mu \mathrm{g} / \mathrm{mL}$ and $0.9 \mu \mathrm{g} / \mathrm{mL}$, respectively [38]. Bationo et al. [21] evaluated antioxidant activities of butanol and ethyl acetate fruit and leaf extracts of $L$. microcarpa using the DPPH free radical scavenging assay. Both extracts showed activities with $\mathrm{IC}_{50}$ values ranging from $1.6 \mu \mathrm{g} / \mathrm{mL}$ to $46.7 \mu \mathrm{g} / \mathrm{mL}$ [21]. Ajiboye et al. [50] evaluated the capability of anthocyanin fruit extract of $L$. microcarpa to scavenge reactive oxygen species and stall aflatoxin B1-mediated oxidative rout on cellular proteins, lipids and DNA using DPPH radical, superoxide anion radical, hydrogen peroxide, hydroxyl radical and ferric ion reducing system assays. The anthocyanins extract at $1.0 \mathrm{mg} / \mathrm{mL}$ scavenged DPPH, superoxide ion, hydrogen peroxide, and hydroxyl radical by $91 \%, 88 \%, 90 \%$ and $83 \%$, respectively, and it also reduced ferric ion. All these results were similar to those demonstrated by vitamin $\mathrm{C}$, used as a reference antioxidant and the reducing effect of the anthocyanin extract on ferric ion was similar to that produced by ascorbic acid used as reference. These results showed that fruit anthocyanins of $L$. microcarpa possess antioxidant properties and halted aflatoxin B1-mediated oxidative rout on cellular proteins, lipids and DNA [50]. Bationo et al. [48] evaluated antioxidant activities of crude hydro-acetonic fruit and leaf extracts of $L$. microcarpa by determining the iron reduction by extracts with ascorbic acid as the reference compound. The reducing power exhibited by fruit extracts and its fractions ranged from $0.4 \pm 0.0$ to $0.8 \pm 0.0 \mathrm{mg} \mathrm{AAE} / 100 \mathrm{mg}$, and $3.8 \pm 0.1$ to $9.5 \pm 0.3$ $\mathrm{mg} \mathrm{AAE} / 100 \mathrm{mg}$ for leaf extract and its fractions [48]. Hilou et al. [39] evaluated antioxidant activities of aqueous, chloroform, ethanol, hexane, methanol and petroleum ether seed extracts of $L$. microcarpa using the DPPH free radical scavenging and FRAP assays with ascorbic acid as the control. The extracts showed activities with $\mathrm{IC}_{50}$ values ranging from $1.4 \mu \mathrm{g} / \mathrm{mL}$ to $1375.8 \mu \mathrm{g} / \mathrm{mL}$ against $\mathrm{IC}_{50}$ value of $4.0 \mu \mathrm{g} / \mathrm{mL}$ exhibited by ascorbic acid, the control. All the extracts exhibited activities in the reduction of $\mathrm{Fe}^{4+}$ to $\mathrm{Fe}^{2+}$ with antioxidant activities ranging from $2.7 \mathrm{mg} \mathrm{AAE} / \mathrm{g}$ to $51.0 \mathrm{mg} \mathrm{AAE} / \mathrm{g}$ [39].

\section{Antiprotozoal and Antitrypanosomal Activities}

Aderbauer et al. [35] evaluated antitrypanosomal activities of dichloromethane leaf and stem bark extracts of $L$. microcarpa using the long-term viability assay on Trypanosoma brucei brucei. Only leaf extracts showed activities with MIC-values of $200 \mu \mathrm{g} / \mathrm{ml}$ [35]. Similarly, Bello et al. [51] evaluated antiprotozoal activities of hexane, chloroform and methanol leaf extracts of $L$. microcarpa using an in vitro assay that involved promastigotes and axenic amastigotes of Leishmania donovani and Trypanosoma brucei brucei. Only methanol extracts exhibited moderate activities with $\mathrm{IC}_{50}$ value of $15.2 \mu \mathrm{g} / \mathrm{ml}$ [51]. These results support the traditional usage of leaves and stem bark of $L$. microcarpa as herbal medicine against trypanosomosis $[27,35,36]$.

\section{Inhibition of $\alpha$-Amylase}

Hilou et al. [39] evaluated the $\alpha$-amylase inhibitory activities of ethanol seed extracts of $L$. microcarpa using the dinitrosalicylate assay. The extract showed activities with $I_{50}$ value of $11.5 \mathrm{mg} / \mathrm{mL}$ against $I C_{50}$ value of $0.62 \mathrm{mg} / \mathrm{mL}$ exhibited by ascarbose, the control [39].

\section{Shea Butter Stabilization}

Hilou et al. [39] evaluated shea butter stabilization activities of chloroform, hexane and petroleum ether seed extracts of $L$. microcarpa using the Rancimat method. The extracts decreased the oxidation of endogenous lipids from shea butter with an increase going from $87.5 \%$ to $91.5 \%$ in the Rancimat induction time shea butter [39].

\section{Trypsin Inhibition}

Hilou et al. [39] evaluated the trypsin inhibition activities of ethanol seed extracts of L. microcarpa using the test of trypsin inhibition as described by Kakade [52]. The extract showed activities with IC50 
value of $12.8 \mathrm{mg} / \mathrm{mL}$ [39]. The weak trypsin inhibition activities exhibited by $L$. microcarpa extracts imply that the seed extracts of the species may be easily digested by ruminants [39].

\section{CONCLUSION}

The present review summarizes the medicinal uses, phytochemistry and pharmacological properties of $L$. microcarpa. Results of this study revealed some research gaps in the phytochemical and pharmacological analyses of the crude extracts of the species as well as compounds identified from the species. There is need to correlate the medicinal uses of the species with the chemical compounds and pharmacological properties of the species. Detailed research on pharmacokinetics, in vivo and clinical research involving plant extracts and compounds isolated from the species are required. Future research should also focus on the toxicological properties of the compounds isolated from the species as well as its crude extracts. Since L. microcarpa is used in combination with other plant species in various herbal concoctions, it is important to evaluate the synergistic effects of the different extracts and their ability to enhance the efficacy of the additive mixtures.

\section{AUTHORS' CONTRIBUTIONS}

I declare that this work was done by the author named in this article.

\section{CONFLICT OF INTEREST}

No conflict of interest is associated with this work.

\section{ACKNOWLEDGEMENTS}

The author would like to express his gratitude to the National Research Foundation (NRF), South Africa and Govan Mbeki Research and Development Centre (GMRDC), University of Fort Hare for financial support to conduct this study.

\section{REFERENCES}

[1] Palmer E, Pitman N. Trees of southern Africa covering all known indigenous species in the Republic of South Africa, South-West Africa, Botswana, Lesotho and Swaziland. Cape Town: Balkema 1972.

[2] Marquet A, Jansen PCM. Lannea microcarpa Engl. \& K. Krause. In: Jansen PCM, Cardon D, editors. Plant resources of tropical Africa 3: dyes and tannins. Wageningen: PROTA Foundation 2005; pp. 102-104

[3] Bazongo P, Bassolé IHN, et al. Characteristics, composition and oxydative stability of Lannea microcarpa seed and seed oil. Molecules 2014; 19: 2684-2693.

https://doi.org/10.3390/molecules 19022684
[4]

Yunus MM, Zuru AA, et al. Assessment of physicochemical proprieties of biodiesel from African grape (Lannea microcarpa Engl. \& K. Krause). Nigeria Journal of Basic and Applied Science 2013; 21(2): 127-130.

http://dx.doi.org/10.4314/njbas.v21i2.7

[5] Sinsin B, Kampmann D. Atlas de la biodiversité de l'Afrique de l'ouest, Tome i: Bénin. Cotonou and Frankfurt/Main; 2010.

[6] Haarmeyer $\mathrm{DH}$, Schumann $\mathrm{K}$, et al. Human impact on population structure and fruit production of the socioeconomically important tree Lannea microcarpa in Burkina Faso. Agroforestry Systems 2013; 87: 1363-1375. http://dx.doi.org/10.1007/s10457-013-9644-7

[7] Diop AG, Sakho $M$, et al. Le baobab africain (Adansonia digitata $L$.): principales caractéristiques et utilisations. Fruits 2005; 61(1): 55-69. http://dx.doi.org/10.1051/fruits:2006005

[8] Vodouhê GF, Coulibaly $\mathrm{O}$, et al. Estimating local values of non-timber forest products to Pendjari biosphere reserve dwellers in Benin. Economic Botany 2009; 63(4): 397-412. http://dx.doi.org/10.1007/s12231-009-9102-7

[9] Goudégnon EOA, Vodouhê FG, et al. Ethnic and generational differences in traditional knowledge and cultural importance of Lannea microcarpa Engl. \& K. Krause in Benin's Sudanian savannah. Bois et Forêts Des Tropiques 2017; 334(4): 49-59.

[10] Guigma $Y$, Zerbo $P$, et al. Retail sale of wild edible fruits in urban areas of sub-Saharan Africa: a case study in Ouagadougou Burkina Faso. International Journal of Agriculture Innovations and Research 2014; 2(4): 561-566.

[11] Yaradua SS, El-Ghani MA. Ethnobotanical survey of edible plants sold in Katsina metropolis markets. International Journal of Science and Research 2014; 4(12): 884-889.

[12] Leßmeister A, Schumann K, et al. Substitution of the most important and declining wild food species in southeast Burkina Faso. Flora et Vegetatio Sudano-Sambesica 2015; 18: $11-20$.

http://dx.doi.org/10.13140/RG.2.2.22067.02089

[13] Ouédraogo $P$, Bationo BA, et al. Uses and vulnerability of ligneous species exploited by local population of northern Burkina Faso in their adaptation strategies to changing environments. Agriculture and Food Security 2017; 6: 15. http://dx.doi.org/10.1186/s40066-017-0090-z

[14] Agbani PO, Kafoutchoni KM, et al. Traditional ecological knowledge-based assessment of threatened woody species and their potential substitutes in the Atakora mountain chain a threatened hotspot of biodiversity in northwestern Benin, West Africa. Journal of Ethnobiology and Ethnomedicine 2018; 14: 21. https://doi.org/10.1186/s13002-018-0219-6

[15] Abubakar US, Khalifa BI, et al. Threatened medicinal plants of Kano flora and the need for urgent conservation. International Journal of Conservation Science 2018; 9(1): 173-178.

[16] Inngjerdingen K, Nergård CS, et al. An ethnopharmacological survey of plants used for wound healing in Dogonland, Mali, west Africa. Journal of Ethnopharmacology 2004; 92: 233244.

https://doi.org/10.1016/j.jep.2004.02.021

[17] Hilou A, Rappez F, Duez P. Ethnoveterinary management of cattle helminthiasis among the Fulani and the Mossi (centra Burkina Faso): plants used and modes of use. International Journal of Biological and Chemical Sciences 2014; 8(5): 2207-2221.

https://doi.org/10.4314/ijbcs.v8i5.24

[18] Adebisi IM, Alebiosu OC. A survey of herbal abortificients and contraceptives in Sokoto, north-west Nigeria. International Journal of Current Research in Chemistry and Pharmaceutical Sciences 2014; 1(7): 81-87.

[19] Cakpo YT, Tovissodé C, et al. Ethnobotanic assessment of debarked medicinal plants in southern Benin: the case of 
Lokoli swampy forest and Lama protected forest. International Journal of Agriculture and Environmental Research 2017; 3(3): 3036-3061.

[20] Abubakar MS, Musa AM, et al. The perception and practice of traditional medicine in the treatment of cancers and inflammations by the Hausa and Fulani tribes of northern Nigeria. Journal of Ethnopharmacology 2007; 111: 625-629. https://doi.org/10.1016/j.jep.2007.01.011

[21] Bationo JH, Hilou A, et al. Content of polyphenolics constituents and the antioxidant and antimicrobial activities of extracts from leaves and fruits of Lannea microcarpa Engl. \& K. Kraus (Anacardiaceae). Current Research Journal of Biological Sciences 2012; 4(3): 290-296.

[22] Irvine FR. Woody plants of Ghana with special reference to their uses. Oxford: Oxford University Press; 1961.

[23] Nadembega P, Boussim Jl, et al. Medicinal plants in Baskoure, Kourittenga province, Burkina Faso: an ethnobotanical study. Journal of Ethnopharmacology 2011; 133: 378-395.

https://doi.org/10.1016/j.jep.2010.10.010

[24] Tibiri A, Sawadogo W, et al. Indigenous knowledge of medicinal plants among Dozo hunters: an ethnobotanical survey in Niamberla village, Burkina Faso. The Journal of Alternative and Complementary Medicine 2015; 21(5): 294303.

https://doi.org/10.1089/acm.2014.0016

[25] Sore $\mathrm{H}$, Hilou A, et al. Dyeing and medicinal plants used in the area of Mouhoun in Burkina Faso. Universal Journal of Environmental Research and Technology 2012; 2(3): 110118.

[26] Jiofack T, Fokunang $\mathrm{C}$, et al. Ethnobotanical uses of medicinal plants of two ethnoecological regions of Cameroon. International Journal of Medicine and Medical Sciences 2010; 2(3): 60-79.

[27] Bizimana N, Tietjen U, et al. Evaluation of medicinal plants from Mali for their in vitro and in vivo trypanocidal activity. Journal of Ethnopharmacology 2006; 103: 350-356. https://doi.org/10.1016/j.jep.2005.08.023

[28] China TFC, Olounlade PA, Salifou S. 2014. Ethnobotanical study of endogenous methods used for the treatment of diseases of Somba cattle breed in northern Benin. Journal of Drug Delivery and Therapeutics 2014; 4(3): 91-99.

[29] Mustapha AA. Ethnobotanical field survey of medicinal plants used by traditional medicine practitioners to manage HIVIAIDS opportunistic infections and their prophylaxis in Keffi Metropolis, Nigeria. Asian Journal of Plant Science and Research 2014; 4(1): 7-14.

[30] Ouédraogo S, Sombié BC, et al. Standardization of extracts from trunks's barks of Lannea microcarpa Engl. and $\mathrm{K}$. Krause (Anacardiaceae) and Anogeissus leiocarpus (DC) Guill. and Perr. (Combretaceae) for the formulation of antihypertensive herbal medicines. International Journal of Pharmaceutical Sciences Review and Research 2018; 48(1): 92-97.

[31] Dossou-Yovo HO, Vodouhe FG, Sinsin B. Assessment of the medicinal uses of plant species found on termitaria in the Pendjari biosphere reserve in Benin. Journal of Medicinal Plants Research 2014; 8(8): 368-377. https://doi.org/10.5897/JMPR10.124

[32] Tapsoba H, Deschamps J-P. Use of medicinal plants for the treatment of oral diseases in Burkina Faso. Journal of Ethnopharmacology 2006; 104: 68-78. https://doi.org/10.1016/j.jep.2005.08.047

[33] Pare D, Hilou A, et al. Ethnobotanical study of medicinal plants used as anti-obesity remedies in the nomad and hunter communities of Burkina Faso. Medicines 2016; 3: 9. https://doi.org/10.3390/medicines3020009

[34] Diallo D, Sogn C, et al. Wound healing plants in Mali, the Bamako region: an ethnobotanical survey and complement fixation of water extracts from selected plants. Pharmaceutical Biology 2002; 40(2): 117-128. https://doi.org/10.1076/phbi.40.2.117.5846

[35] Aderbauer $\mathrm{B}$, Clausen $\mathrm{P}-\mathrm{H}$, et al. In vitro and in vivo trypanocidal effect of lipophilic extracts of medicinal plants from Mali and Burkina Faso. Journal of Ethnopharmacology 2008; 119: 225-231.

https://doi.org/10.1016/j.jep.2008.06.024

[36] André $\mathrm{Z}$, Adama $\mathrm{K}$, et al. Constraints of ruminant rearing and ethno-veterinary practice against African animal trypanosomosis in the pastoral area of Gaongho in Burkina Faso. Animal and Veterinary Sciences 2017; 5(1): 1-7. https://doi.org/10.11648/j.avs.20170501.11

[37] Lamien-Meda A, Lamien CE, et al. Polyphenol content and antioxidant activity of fourteen wild edible fruits from Burkina Faso. Molecules 2008; 13: 581-594. https://doi.org/10.3390/molecules 13030581

[38] Ouattara L, Koudou J, et al. Antioxidant and antibacterial activities of three species of Lannea from Burkina Faso. Journal of Applied Sciences 2011; 11(2): 157-162. https://doi.org/10.3923/jas.2011.157.162

[39] Hilou A, Bougma A, Dicko MH. Phytochemistry and agroindustrial potential of native oilseeds from west Africa: African grape (Lannea microcarpa), marula (Sclerocarya birrea), and butter tree (Pentadesma butyracea). Agriculture 2017; 7: 24. https://doi.org/10.3390/agriculture7030024

[40] Glew RH, Van der Jagt DJ, et al. Amino acid, fatty acid, and mineral composition of 24 indigenous plants of Burkina Faso. Journal of Food Composition and Analysis 1997; 10: 205217.

\section{https://doi.org/10.1006/jfca.1997.0539}

[41] Pale E. 1998. Contribution to the study of anthocyanin compounds in plants: the case of Hibiscus sabdariffa, Lannea microcapa and Vigna sorghum caudatum from Burkina Faso. PhD Thesis, University of Ouagadougou, Burkina Faso.

[42] Picerno $\mathrm{P}$, Mencherini $\mathrm{T}$, et al. An extract of Lannea microcarpa: composition, activity and evaluation of cutaneous irritation in cell cultures and reconstituted human epidermis. Journal of Pharmacy and Pharmacology 2006; 58: 981-988. https://doi.org/10.1211/jpp.58.7.0014

[43] Ellis RH, Hong TD, Roberts EH. An intermediate category of seed storage behaviour. i coffee. Journal of Experimental Botany 1990; 41: 1167-1174.

[44] Bugaje IM, Umar I. Assessment of oilseeds for biodiesel production in Nigeria: Vitex doniana and Lannea microcarpa. $1^{\text {st }}$ International Conference on New Frontiers in Biofuels 2010; $1-5$.

[45] Danladi GH, Muhammad S, et al. Antimicrobial activity of Anogeissus leiocarpus and Lannea microcarpa on some microbes isolated from vegetables in Sokoto. International Conference on Chemical, Environmental and Biological Sciences (CEBS-2015) March 18-19, 2015 Dubai (UAE).

[46] Ouedraogo S, Belemnaba L, et al. Endothelium independent vasorelation by extract and fractions from Lannea microcarpa Engl. and K. Krause (Anacardiaceae): possible involvement of phosphodiesterase inhibition. International Journal of Pharmacology and Biological Sciences 2010; 4(2): 9-16.

[47] Nitiéma M, Belemnaba L, et al. Hypotensive and preventive effects of hypertensive blood by extracts of Lannea microcarpa Engl. and K. Krause (Anacardiaceae): a recipe of traditional medicine in Burkina Faso. African Journal of Traditional Complementary and Alternative Medicine 2015; 12(S): 38.

[48] Bationo $\mathrm{JH}$, Hilou A, et al. Anti-inflammatory activities of fruit and leaves extract of Lannea microcarpa England K. Kraus (Anacardiaceae). International Journal of Pharmacy and Pharmaceutical Sciences 2015; 7: 177-182. 
[49] Antwi-Adjei M, Owusu G, Ameade EPK. Aqueous extract of Lannea microcarpa attenuates dextran sulphate induced paw oedema and xylene-induced ear oedema in rodents. International Journal of Basic and Clinical Pharmacology 2017; 6(5): 1048-1053.

http://dx.doi.org/10.18203/2319-2003.ijbcp20171655

[50] Ajiboye TO, Raji HO, et al. Anthocyanin extract of Lannea microcarpa fruits stall oxidative rout associated with aflatoxin B1 hepatocarcinogenesis. Food Bioscience 2013; 4: 58-67. https://doi.org/10.1016/j.fbio.2013.09.002
[51] Bello OM, Zaki AA, et al. Assessment of selected medicinal plants indigenous to west Africa for antiprotozoal activity. South African Journal of Botany 2017; 113: 200-211. https://doi.org/10.1016/j.sajb.2017.08.002

[52] Kakade ML, Rackis JJ, et al. Determination of trypsin inhibitor activity of soy products: a collaborative analysis of an improved procedure. Cereal Chemistry 1974; 51: 376381. 